\title{
MORPHOLOGICAL AND ECOLOGICAL OBSERVATIONS ON CHIROMANTIS VITTIGER (ANURA: RHACOPHORIDAE) IN MOUNT HALIMUN - SALAK NATIONAL PARK, INDONESIA
}

\author{
Mirza Dikari Kusrini*1, Muhammad Irfansyah Lubis $^{2}$, Boby Darmawan ${ }^{3}$ and Luthfia Nuraini ${ }^{1}$ \\ ${ }^{1}$ Bogor Agricultural University, Faculty of Forestry, Forest Resources Conservation and Ecotourism, J1. Lingkar \\ Akademik Kampus IPB, Dramaga, Bogor 16680, Indonesia \\ ${ }^{2}$ Wildlife Conservation Society - Indonesia Programme, \\ Jl. Tampomas Ujung No. 35, Babakan, Bogor 16151, Indonesia \\ ${ }^{3}$ Ministry of Environment and Forestry, Komodo National Park, \\ Jl. Kasimo, Labuan Bajo, Manggarai Barat, Flores 86554, NTT, Indonesia \\ *Corresponding author: mirza_kusrini@yahoo.com
}

Received: 14 June 2017; Accepted: 23 November 2017

\begin{abstract}
Despite an early description, the rhacophorid frog (Chiromantis vittiger (Boulenger 1897)) is relatively poorly known species. It has been found in several areas in the mountainous part of western Java, one of which is in the Chevron Geothermal Indonesia (CGI) concession area within Mount Halimun-Salak National Park. An ecological study of this species and its habitat was conducted in CGI from April to September 2008. The biological and ecological aspects of this tree frog such as morphology, habitat characteristics, breeding behaviour, and larval development are presented in this paper. This study found that the fertilised eggs hatch as free-swimming tadpoles. In addition, the availability of artificial habitat in the form of concrete ponds helps sustain the population throughout the year. We also report parental care in this species.
\end{abstract}

Key words: breeding behaviour, Chiromantis vittiger, larval development, Mount Halimun-Salak National Park, parental care

\section{INTRODUCTION}

One problem of amphibian conservation in developing countries is a lack of information on frog species and their ecology and behaviour (Alford \& Richards 1999). In the past couple of years, studies have shown that amphibian listed as Data Deficient species in IUCN Red List are at risk of extinction (Morais et al. 2013, Howard \& Bickford 2014, Nori \& Loyola 2015). The need to study Data Deficient species is greater as the conservation crisis is escalating in Southeast Asia (Rowley et al. 2010) including Indonesia (Iskandar \& Erdelen 2004). Destruction of forests, habitat fragmentation, climate change, and diseases are some of the factors that may affect the populations of amphibians (Stuart et al. 2005). Amphibians are more sensitive to environmental toxins or to changes in patterns of temperature or rainfall than are other terrestrial vertebrate (Alford \& Richards 1999), thus making them more susceptible to environmental stressor. In addition, some of the peculiar life-history characteristics of amphibian such as parental care, breeding behaviour, and various kinds of larva development are under studied especially in Southeast Asia (Poo \& Bickford 2013). In fact, this information is essential to enhance our understanding of the ecological and evolutionary significance of amphibians in general. 
Mount Salak (highest elevation 2,211 m) is one of the few remaining pristine habitats in Java. As an area that harbours multiple waterfalls and forest ecosystems, Mount Salak was designated as Halimun-Salak National Park (113,357 ha) in 2003. A small part ( \pm 110 ha) of this national park is managed by Chevron Geothermal Indonesia (CGI) for geothermal energy and most of the area consists of natural forests. In 2006, an amphibian survey was conducted in CGI area, mostly along the gravel path used by the workers to check on the gas pipelines in several blocks. Two individuals of Chiromantis vittiger (Boulenger 1897) were found in one of the ponds inside this area (Kusrini \& Fitri 2006). This species have been identified in several areas of West Java; these include populations in Situ Lembang and Mount Burangrang (Iskandar 1998), Mount Halimun (Kurniati 2003) and Mount Salak (Kusrini \& Fitri 2006). This spesies is known to inhabit high elevation locations ( $>900 \mathrm{~m}$ above sea level) and is mostly found near ponds or stagnant waters (Kurniati 2003, Kusrini \& Fitri 2006), but detailed descriptions of its habitat preferences are lacking. Recently Wostl et al. (2017) transferred Philautus vittiger to Chiromantis vittiger based on its morphological characteristic. Thus in this paper we refer P. vittiger into Chiromantis vittiger. Wostl et al. (2017) however did not give any additional information regarding the ecology of the species.

We studied the autoecology of $C$. vittiger which has never been studied and the species has been listed as Data Deficient by the International Union for the Conservation of Nature (Iskandar et al. 2009). Here, we presented its habitat characteristics, along with breeding behaviour and reproductive ecology.

\section{MATERIALS AND METHODS}

This study was conducted in Chevron Geothermal Indonesia (CGI) concession, within the Halimun-Salak National Park in West Java (Fig. 1). The site lies at elevations between 950-1,050 m above sea level and the forested areas are dominated with trees such as Schima wallichii, Quercus lineata, Altingia excels and shrubs such as Cyathea sp. and Pandanus sp. Based on 2005-2007 monthly rainfall statistics from Parakan Salak's rainfall station (approx. $20 \mathrm{~km}$ in distance), the area receives rainfall every month, with the highest intensity of rain from October to April (up to 350 $\mathrm{mm} / \mathrm{mth}$ ) and lowest intensity of rain from May to September (lowest recorded level of rainfall is $75 \mathrm{~mm}$ in August), resulting in almost year-round occurrence of permanent streams and ponds. A tea plantation separated the CGI concession with the villages below.

The study was conducted from April to September 2008. A distributional survey was conducted by 4-5 persons for 4 nights in a row each month from April to June 2008. Comprehensive night surveys were carried out in streams, ponds and terrestrial habitat within the concession area, mostly near the gas checking point (coded as P for short). A 400-m transect survey was conducted in five streams. We employed a $\chi^{2}$ test for independence in order to verify if frogs 
were randomly distributed or more likely to occur in specific habitat type. When possible, we measured the snout vent length (SVL) of males and females of the $C$. vittiger to the nearest $0.1 \mathrm{~mm}$ with callipers and weighed body mass to the nearest $0.5 \mathrm{~g}$ with a Pesola spring scale. We then analysed the difference of mass and length between male and female using t-test. All the statistical analysis were carried out using $\mathrm{R}$ software ( $\mathrm{R}$ Core Team 2017). We also observed the gravid condition of females based on visible ova: no ova or with ova. The latter was categorised further as gravid or ready to breed in which the ova were bigger than those in gravid female.

Breeding observations were carried out from April to September 2008. We visited the ponds and waterways where we encountered $C$. vittiger at least once a day for 3-5 nights each month and searched for newly-laid eggs. Visual Encounter Survey (VES) was used mostly at night with a total of 77 man-hours. When we found egg masses, we recorded habitat characteristics such as height of egg-mass (measured from the surface of the pond to their lower margin to the nearest $0.1 \mathrm{~m}$ ), air and water temperature, type of water body (standing or moving water), type of leaf to which egg mass was attached (small or large-sized), and vegetation structure (shrubs, liana and trees). We measured air temperature and relative humidity using a thermohygrometer, $\mathrm{pH}$ of water using $\mathrm{pH}$ strip paper and water temperature using thermometer. We noted type and species of vegetation around the area and also perching vegetations. We defined shrub as any woody vegetation or a woody plant having multiple stems and bearing foliage from the ground up. Ferns are vascular plants that reproduce via spores and can be epiphyte or terrestrial. Trees are any woody plant, normally having one stem or trunk bearing its foliage or crown well above ground level to heights of 5 meters or more. A liana is a woody climber that starts at ground level, and uses trees to climb up to the canopy.

During the survey we noted breeding behaviour including parental care, and larval development. Calls were recorded whenever possible using a digital recorder Edirol R-09 HR with built-in microphone. A call from a male at P5 taken at 31 May 2008 (21:34) with an air temperature of $19^{\circ} \mathrm{C}$, and was analysed using SoundRuler Acoustic Analysis version 0.9.6.0. (Gridi-Papp 2007).

Observations on breeding behaviour were made at night whenever breeding occurrences were found. We recorded courtship interaction (male and female conducted pair formation and mating), and after eggs were laid, the occurrence of parental care if any. To obtain detailed information of breeding sequence we constructed an artificial terrarium in base camp (about $2 \mathrm{~km}$ from the CGI concession area). We used a 30x20x21 cm plastic box, one-quarter full of water, and added aquatic plants. Two males (SVL $27.9 \mathrm{~mm}$ and $28.4 \mathrm{~mm}$ ) and three females (SVL $21.6 \mathrm{~mm}$, $24.4 \mathrm{~mm}$ and $24.3 \mathrm{~mm}$ ) were taken on 23 September 2008 from two locations (one pair from P3 and the others from P4). All females showed visible ova, although only one showed mature ova (large and yellowish in colour). One female escaped after six hours in captivity, thus observations were 

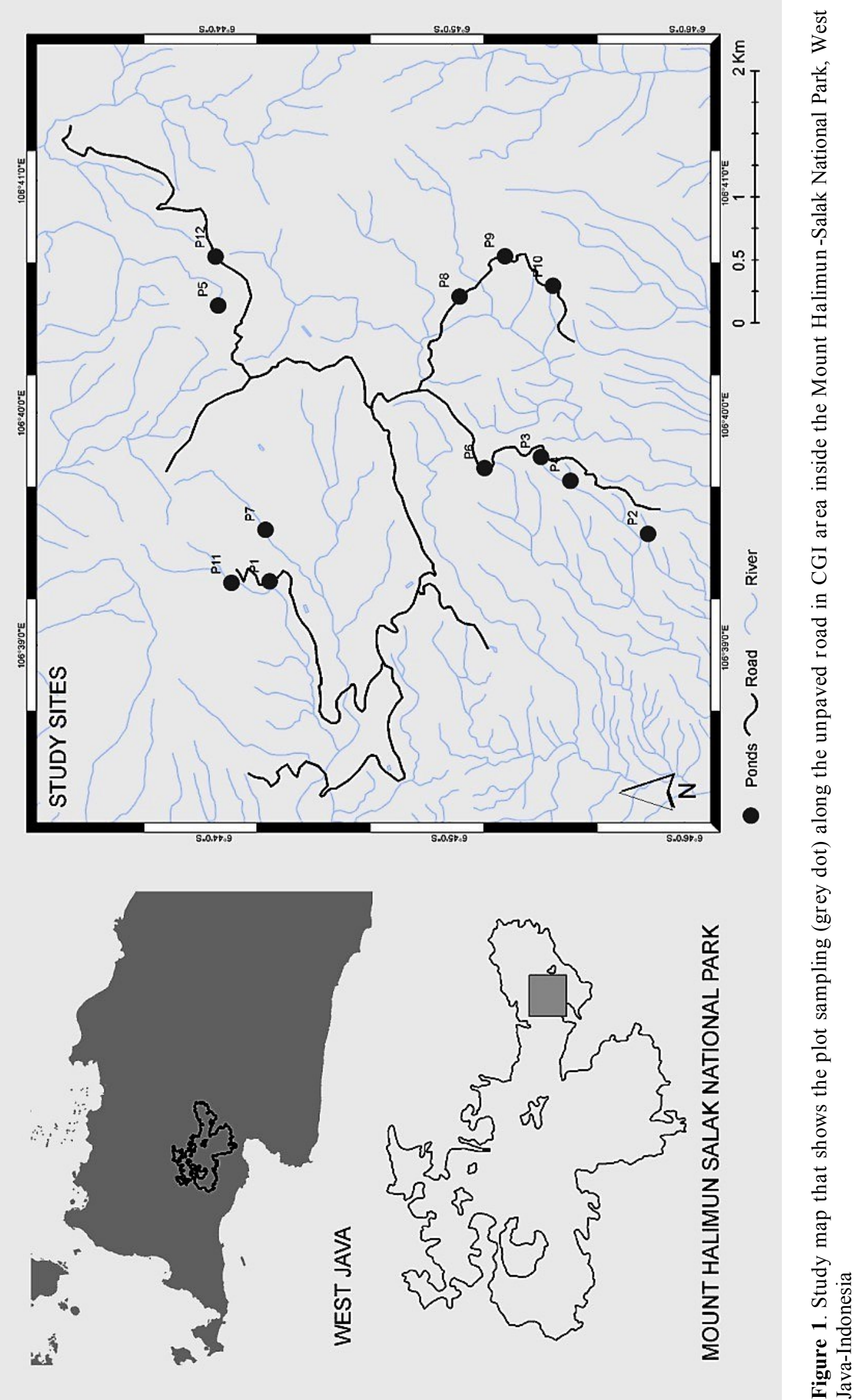
made only for the remaining 4 frogs. Observations were conducted for three days in a row. Afterwards frogs were released back to their original habitats.

We observed larval development in the field as well as in laboratory using terrariums to mimic its natural habitat. We determined clutch size by counting the number of eggs from a digital image or, in the case of eggs reared in the lab, by counting the number that hatched and failed to hatch. We documented the number of egg-masses present in each clutch and assessed changes in development of egg masses found in the previous month following Gosner stage (1960) and mortality, if any. Each clutch's location in the field was noted and revisited each subsequent month until September 2008.

Development of three clutches of eggs plus 14 tadpoles (stage 24 to 42) was observed in the laboratory (Wildlife Ecology Lab, Faculty of Forestry, Bogor Agricultural University, Bogor, Indonesia). The tadpoles were captured from one of the surveyed ponds (P1) and brought in to the lab on 03 June 2008. The first clutch of eggs observed in the lab resulted from the mating of a pair of frogs that was brought back to the lab on 29 August 2008. In this case, a pair of C. vittiger (female already gravid - eggs were visible inside the body cavity) were captured and placed into a plastic bag $(30 \times 40 \mathrm{~cm})$ together with a branch and leaves and brought into lab. In the lab, the pair was put inside an enclosure $(21 \times 14 \times 14 \mathrm{~cm})$ and 9 days later a clutch of eggs was observed within the enclosure.

On 29 August 2008, a second clutch was taken from P1. We carefully removed the clutch (embryonic stage 21; Gosner 1960) from a leaf overhanging the pond and placed it inside a plastic bucket (210 1 in volume), filled with pond water and brought it to the lab for monitoring until emergence of hatchlings. The clutch was placed inside a plastic box $(28 \times 22 \times 16 \mathrm{~cm})$ which was held above the water surface on branches and leaves collected from the study site. We added bits of mud and leaf litter from its original habitat and aquatic plants (Hydrila spp.) One additional clutch was collected on 25 September 2008 from a pair that mated in an artificial terrarium in the field-lab. The tadpoles were reared in an aquarium at the lab in Bogor until December 2008. Lab temperature in Bogor ranged $24-25^{\circ} \mathrm{C}$.

\section{RESULTS}

\section{Morphology and call description}

We captured and measured 35 individuals of $C$. vittiger. Mature males (mean SVL $=27.26$ $\mathrm{mm}$ ) are slightly larger than females (mean SVL $=23.99 \mathrm{~mm}$ ), the difference is statistically significant $(\mathrm{t}=-6.877, \mathrm{df}=32.992, \mathrm{p}$-value $=0$; Fig. 2$)$. However, there is no significant difference 

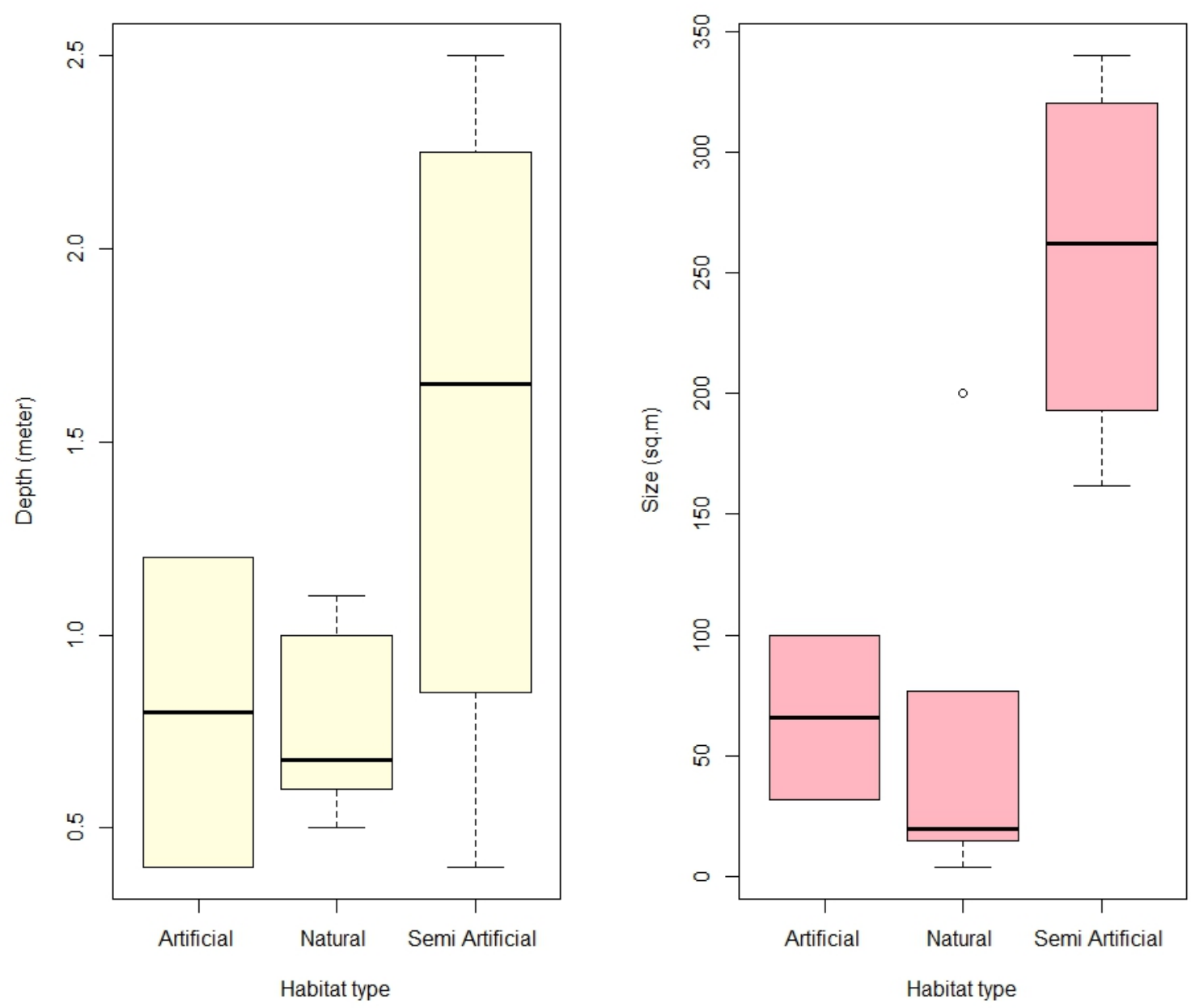

Figure 2. Mean size (snout vent length) and weight of male and female of Chiromantis vittiger at Mount Salak.

in weights of adult males and females (mass $\pm 1.22 \mathrm{~g}, \mathrm{t}=0.69952$, $\mathrm{df}=19.494$, $\mathrm{p}$-value $=0.4925$; Fig. 2). Males were slightly more abundant than females $55 \%$ and $45 \%$, respectively.

Here we provide a short description of the species: Tympanum visible and skin is smooth and without a supratympanic fold. The snout is short and slightly pointed. A dark stripe extends from the eye to the groin, mostly distinctly from the eye to the forelimb. The colouration pattern varies among adults. Dorsum was pale translucent yellow cream (usually at night), sometimes with brown spots or brown bars or even completely brown. The colour pattern can change rapidly within hours, from yellow-cream to yellow-brown. In the lighter version, fore and hind limbs were usually pale pink whilst the brown version usually exhibited yellow fore and hind limbs with brown bars or dark spots all over the limb. Throat to belly was white with the middle part to groin pinkish. The tips of toes and fingers were distinctively enlarged into flattened disc. Fingers were slightly webbed at the base, and toes were $2 / 3$ webbed. The morphology and colouration of this species as observed in the field is shown in Fig. 3. The advertisement call of the $C$. vittiger recorded (31 May 2008, 21:34, air 


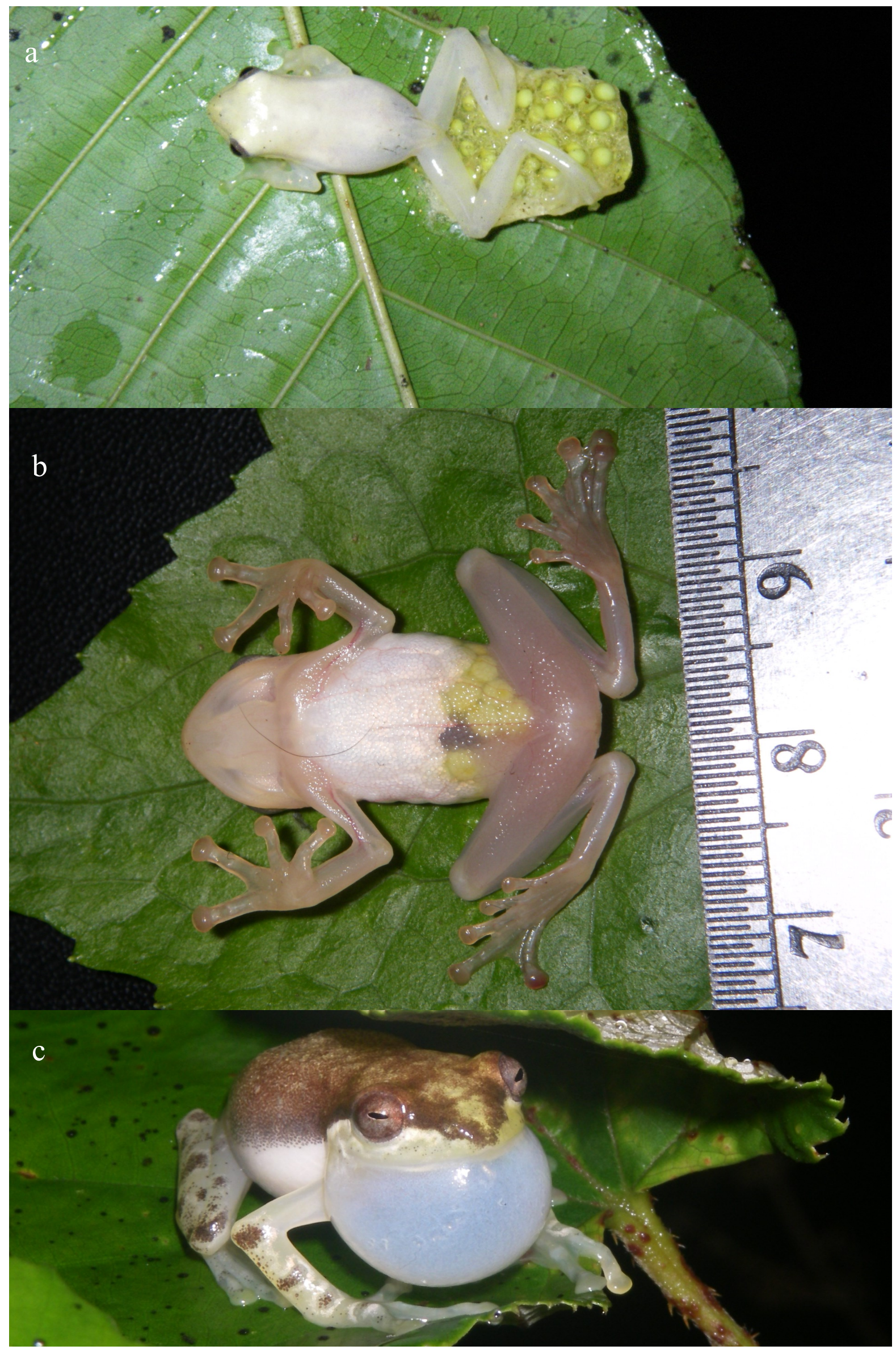

Figure 3. The appearance of $C$. vittiger, (a and b) females with their eggs, and (c) male and its vocal sac. 
temperature of $19{ }^{\circ} \mathrm{C}$ ) composed of a pair of chirps, or clicks of approximately 0.026 second duration, spaced 0.658 seconds apart. The peak frequency of each note was $2.93 \mathrm{kHz}$." (see Fig. 9c). The calls were easily heard from a distance of more than $20 \mathrm{~m}$.

\section{Habitat characteristics}

During the study, we only encountered this frog in ponds surrounded by shrubs. We classified ponds based on its construction to natural ponds, semi artificial ponds, and artificial ponds. The last two types were built by CGI management to retain water for cooling. We found the species to be more abundant in semi-artificial ponds, which originated from slow moving streams impounded by

Figure 4a. Mean size and depth of three types of ponds within the Chrevron Geothermal Indone-

sia concession at Mount Salak. Semi artificial ponds are larger and deeper compared to the other ponds.
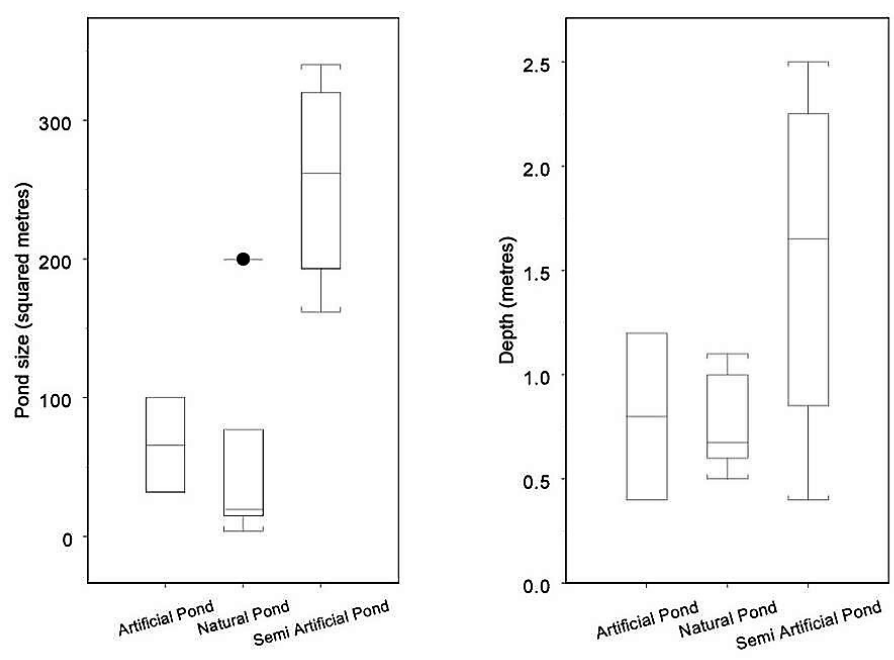

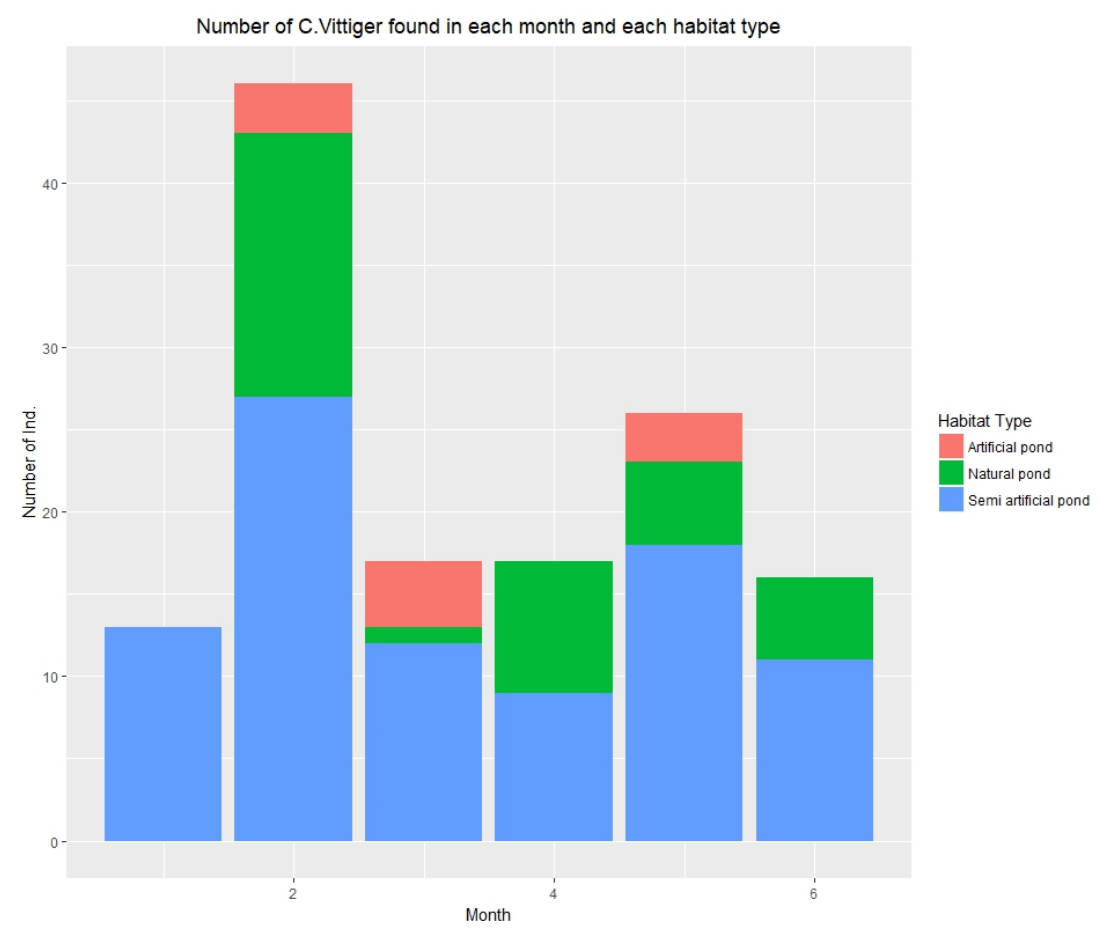

Figure $4 \mathbf{b}$. Number of individuals of C. vittiger during 6 months field observation in different type of habitat. Chiromantis vittiger was found more abundant in semi artificial ponds than in natural and artificial ponds. 
CGI management. This might be due to the availability of water during the dry season. The cemented ponds help retain the water during dry season. Moreover, the semi artificial ponds are larger and deeper than artificial and natural ponds (Fig. 4a). Chi-square test also revealed that the distribution of the frog is likely to occur in semi-artificial ponds $(\mathrm{X}$-squared $=74.444$, $\mathrm{df}=2$, $\mathrm{p}$ value $<2.2 \mathrm{e}-16$; Fig. 4b).

The distribution of the frog also depends on the occurrence of forest and vegetation surrounding the ponds. All the ponds, except the one in the tea plantation, are similar in being surrounded by dense vegetation, mostly shrubs with broad leaves or epiphytes that inhabit moist and wet soils. The information of the vegetation in which we found these tree frogs perching on is given in Table 1.

Table.1. Vegetation types where Chiromantis vittiger usually perching in the study site

\begin{tabular}{clll}
\hline No & Local name & Latin name & Category \\
\hline 1 & Pacar tere & Impatiens platypetala & Shrub \\
2 & Kirinyuh & Eupatorium pallescen & Shrub \\
3 & Pisang hutan & Musa acuminata & Shrub \\
4 & Resam & Dicranoteris linearis & Shrub \\
5 & Sereh tangkal & Piper anducum & Shrub \\
6 & Paku sarang burung & Asplenium nidus & Epiphytic fern \\
7 & Sangketan & Achyranthes bidentata & Shrub \\
8 & Areuy capituheur & Mikania cordata & Shrub \\
9 & Prasman & Eupatorium triplinerve & Shrub \\
10 & Ganda Rusa & Justica gendarrusa & Shrub \\
11 & Paku-pakuan & Nephrolepis biserrata & Terrestrial ferns \\
\hline
\end{tabular}

Males are usually found perching under the overhanging leaves, three meters above the water surface. Leaves are not only used for perching by females, but also for ovipositing. All clutches were attached either under broad leaves or inside coiled leaves to protect the eggs from the direct heat of the sun during the day. Clutches were found in the leaves of Impatiens platypetala, Eupatorium pallescen, Musa acuminata, Mikania cordata and Asplenium nidus.

Water temperatures in ponds were ranging from 18.1 to $26^{\circ} \mathrm{C}$ with $\mathrm{pH}$ of 5.5-7.0. Air temperatures ranged from 17.5 to $26^{\circ} \mathrm{C}$, with humidity ranging from 62 to $98 \%$. The substrates of ponds consisted primarily of decomposed leaves.

Many other species of frogs were found in the ponds and its surrounding area where $C$. vittiger occurs. These species are Chalcorana chalconota (Schlegel, 1837); Fejervarya limnocharis (Gravenhorst, 1829); Amnirana nicobariensis (Stoliczka, 1870), Limnonectes microdiscus (Boettger, 1892); Limnonectes kuhlii (Tschudi, 1838); Microhyla achatina Tschudi, 1838; Microhyla palmipes Boulenger, 1897; Polypedates leucomystax Gravenhorst, 1829; Rhacophorus 
reinwardtii (Schelegel, 1840); and Rhacophorus margaritifer (Schlegel, 1937). Several tadpoles were seen, mostly from species such as C. chalconota, M. palmipes, Leptobrachium hasseltii Tschudi, 1838; and R. margaritifer.

\section{Breeding Behaviour}

No amplexus occurred in the natural habitat during our observation. Even though we have encountered five pairs sitting close to each other, most likely they were associated with reproductive activities. Observations mostly described here are based on experimental activities when two pairs of female and male were kept in a terrarium.

Courtship began a day before with a male calling from under the widest leaf which was situated directly above the water surface. At 22:00 (local time), a female with visible ova began advancing toward the calling male. Both male and female then sat close to each other (around $3 \mathrm{~cm}$ apart). The male continuously called until 5:00 in the following morning. During the day, both were seen resting close together until dusk with the female moving around the water and leaf occasionally. At 18:30, the male started to call again and continued calling until 01:00 am where upon the female advanced upon him and appeared to be searching for a suitable location on the leaf to deposit her eggs. She then sat in the selected location. At 01:10, the calling male advanced toward a non-calling male in the terrarium, but after 10 seconds he left the male and approached the female. Shortly thereafter the pair engaged to axillary amplexus and the male stopped calling (Fig. $5)$.

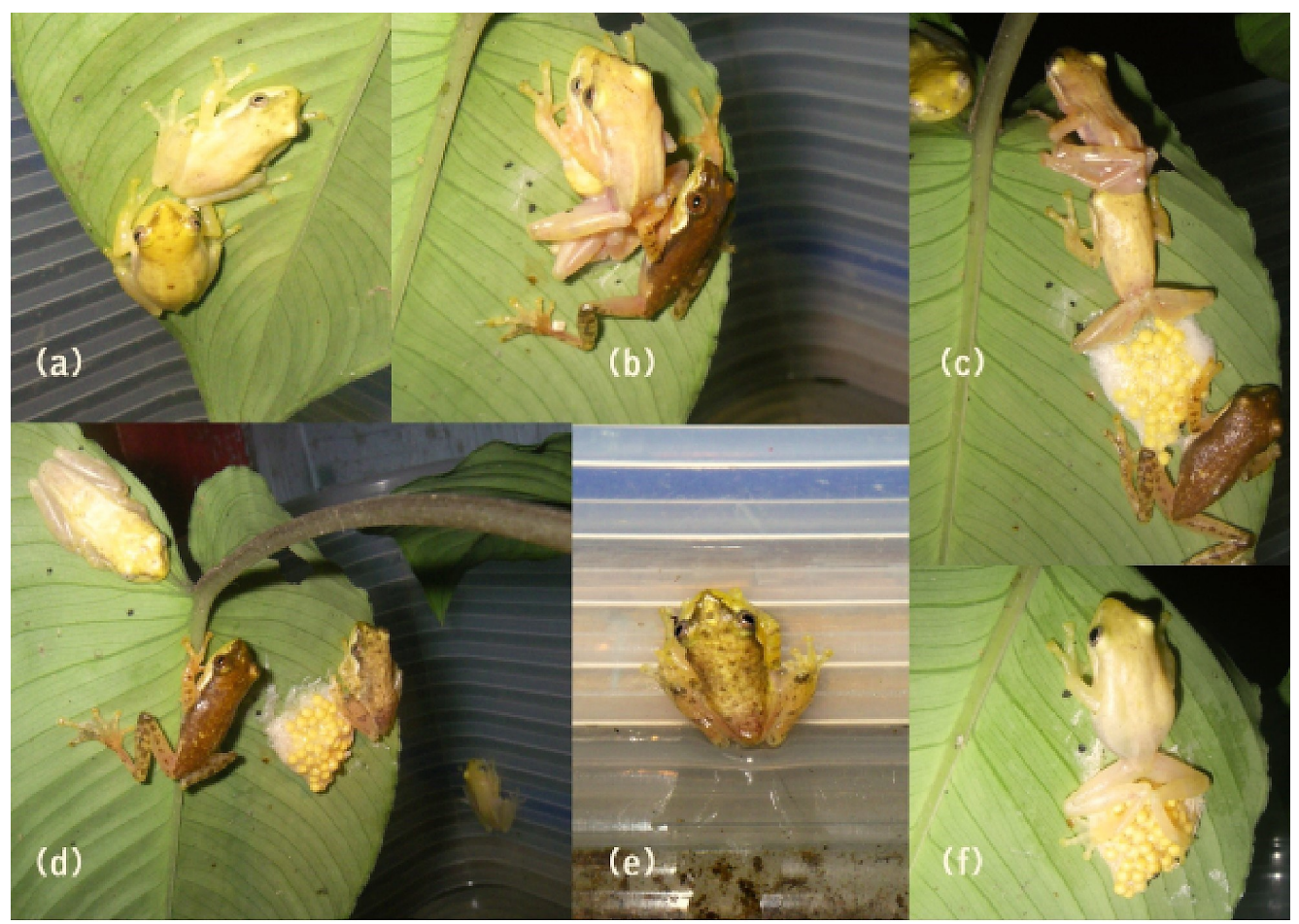

Figure 5. Breeding sequence of Chiromantis vittiger in a terrarium ((a) A female approaching a calling male, (b-d) During amplexus, another (non-calling) male approaching the pair and the eggs, (e) The female left the nest and went down to water, (f) The female sitting and rubbing the eggs with its hind limbs. Note that the non -calling male is shown and appears darker in colour than the other frogs (Photographed by M. I. Lubis). 
During the mating observation, we encountered an interesting mating activity. It began when a non-calling male in the terrarium approached the amplectant pair at 01:29 when the female was laying the eggs. Previously, the non-calling male was waiting about $10 \mathrm{~cm}$ below the amplectant pair. While the female released eggs for 26 minutes with a male on her back, the non-calling male positioned himself on top of the eggs clutch, both males seemingly fertilised them. After eggs were laid (01:55), the first male soon released the female and departed, however the second (non-calling) male remained nearby for the next 32 minutes. The female sat on her eggs for about 3 hours, but intermittently left them for water below the vegetation. At 03:03 am, the first male called from near the water with a third of his body submerged in water. The awaiting female left her eggs and assumed the same position as the male. At 04:11 am, the female left the water and went back to the eggs whilst the male continuously called until 05:00 am. For the next 23 minutes, the female was seen sitting on top of the eggs and rubbing her wet hind legs apparently on them until 04:34. During the day, the female rested near the eggs. The complete sequence of the mating process is given in Fig. 5.

\section{Parental Care}

We observed an apparent parental care of this species in their natural habitat. Most females that were not engaged in breeding activities were usually located near eggs during the day although they were mostly inconspicuous. At night, females occasionally sat on top of their eggs and wiped their hind legs on them (Fig. 2a). Of the 17 clutches we observed, 10 were guarded by a female. A male usually sat nearby but was never as close as the female. These males usually called and when researchers approached them, they increased the tempo of the calls.

At least five out of seven unguarded clutches were damaged. Four clutches were attacked by ants and via fungal infection, in which the eggs rotted, became discoloured, or dried up. On one occasion, a clutch of eggs was abandoned by the guarding female after the leaf sheltering the eggs was eaten by a caterpillar, leaving the eggs hanging only by a small thread of the remaining leaf. There is a possibility that the eggs may have survived because the embryos were already in stage 21. This observation suggests that parental care is required to keep the larva alive and develops.

We found egg clutches at five different locations, but most were found at PP1 (17 clutches). The most clutches (10 egg clutches) were seen in May, but we saw clutches in all six months of the observation period (Fig. 6). Moreover, we also detected calling males throughout this period of study.

Females attending the breeding sites were either gravid or ready to breed or taking care of the clutch (no visible ova in the body cavity). Ripe ova were usually large and yellowish, whilst unripe 
Table 2. Diameter of clutch and egg of $C$. vittiger from five samples

\begin{tabular}{lllll}
\hline Clutch number & $\Sigma$ eggs & Gosner stage & $\Theta$ clutch $(\mathrm{mm})$ & $\Theta \operatorname{egg}(\mathrm{mm})$ \\
\hline 1 & 44 & 20 & 24,08 & 4,38 \\
2 & 58 & 21 & 26,98 & 4,96 \\
3 & 48 & 11 & 13,5 & 3,98 \\
4 & 43 & 20 & 24,6 & 4,66 \\
5 & 62 & 19 & 31,68 & 1,4 \\
\hline
\end{tabular}

Table 3. Embryonic development in $C$. vittiger based from field and laboratory observation. Development duration of eggs is varied; data below shows the fastest development period

\begin{tabular}{llll}
\hline $\begin{array}{l}\text { Developmental } \\
\text { Duration (day) }\end{array}$ & $\begin{array}{l}\text { Day after egg } \\
\text { laid }\end{array}$ & Stage & Development characteristic \\
\hline 2 & 0 & 113 & Unpigmented eggs started to develop \\
3 & 2 & $14-18$ & Embryo elongated, distinct shape of head and tail \\
6 & 5 & $19-20$ & Tail more developed and longer, gills distinct \\
5 & 11 & $21-24$ & Cornea transparent, operculum develop \\
48 & 16 & 25 & Eggs hatched, tadpole drops from leaves to the water below. \\
& & & Tadpoles increase its body size \\
10 & 64 & $26-36$ & Hind limb bud develop but toes not yet distinctive \\
8 & 74 & $37-40$ & Hind limb developed, individual toes look distinct \\
4 & 82 & 41 & Fore limb bud developed \\
1 & 86 & 42 & Fore limb more developed, oral disc begin to change shape \\
1 & 87 & 43 & Tail length diminishes. Changes in mouth part apparent \\
1 & 88 & 44 & Head and mouth longer \\
2 & 89 & 45 & Head shape similar to adult shape, tail absorbed and nearly \\
& & & dissappeared \\
- & 91 & 46 & Juvenile stage, metamorphosis concluded \\
\hline
\end{tabular}

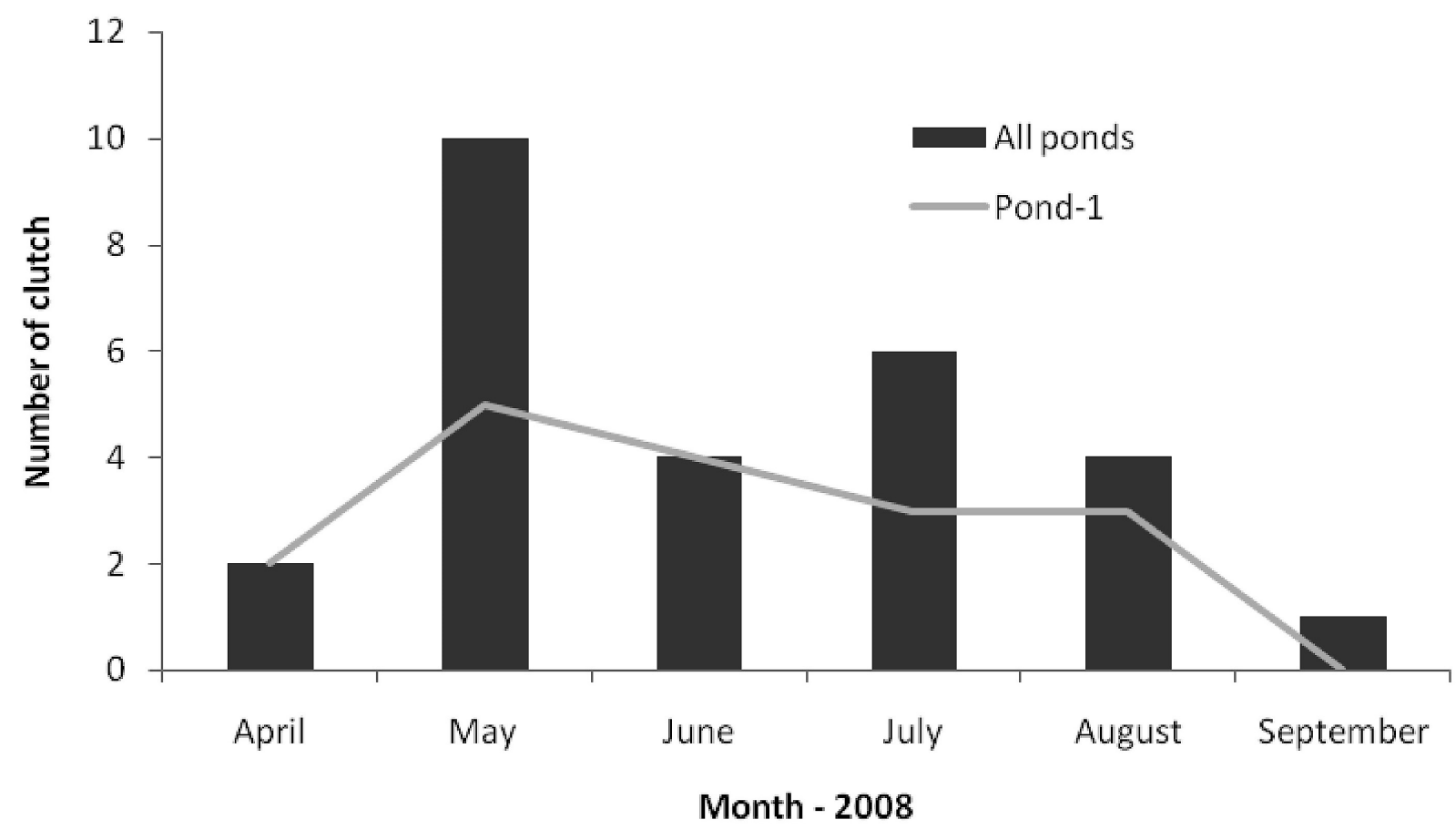

Figure 6. Number of $C$. vittiger egg clutches observed at Chevron Geothermal Indonesia ponds at HalimunSalak National Park from April to September 2008. 
ova were usually smaller and greenish. Breeding females would lay all their eggs, clumped into a single clutch during amplexus (diameter of clutch $13.5 \mathrm{~mm}$ for stage 11 to $26.98 \mathrm{~mm}$ for stage 21 , see Table 2). Mean number of eggs per clutch was 52 (37-66 eggs; $n=12)$. Eggs were unpigmented, pale yellow, and coated by a sticky jelly substance. Egg diameter ranged from 3.98 $\mathrm{mm}$ (stage 11) to $4.96 \mathrm{~mm}$ (stage 21). Mean height of nest position above the pond water was 1.47 $\mathrm{m}(0.2$ to $2.5 \mathrm{~m} ; \mathrm{n}=22)$.

Fertilised eggs hatched after about 16 days, at which time tadpoles emerged as stage 25 and slid into the water below the oviposition site. Tadpoles remained in stage 25 for at least 8 days. After about two months, hind limbs began to develop and after another 20 days, front limbs emerged. The metamorphosis process in the captivity took 3 months based on our observation (Table 3, Fig. 7).

Two attempts to rear newly fertilised eggs in the lab were unsuccessful. In one of the clutches, eggs were guarded by the female until stage 17 when the eggs were attacked by a fungus or mold and was abandoned. Both the mother and the embryos died. The other clutch of newly fertilised eggs taken from the field lab without the parent died in 3 days.

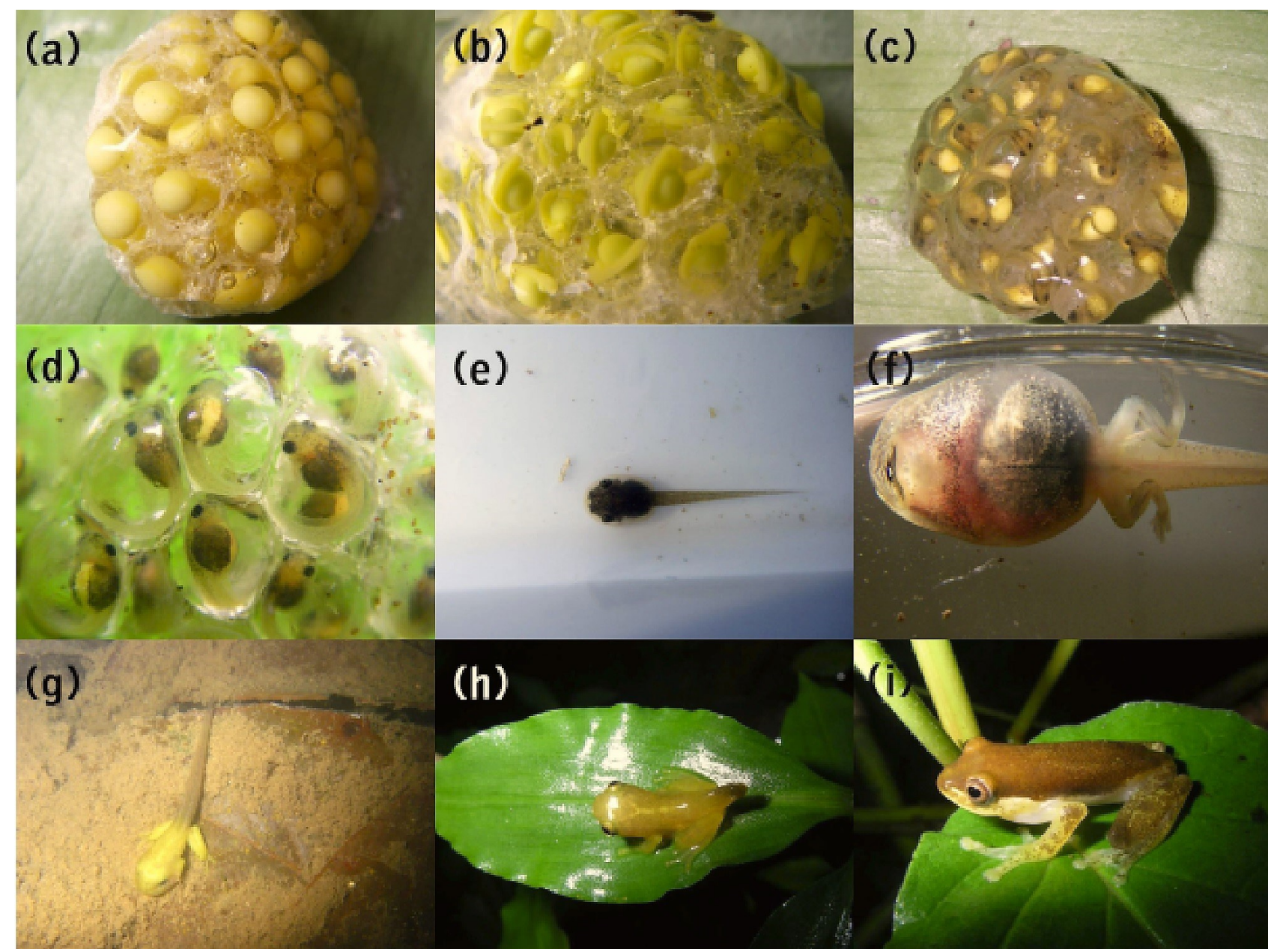

Figure 7. The development of newly fertilised eggs of C. vittiger, started from Gosner; (a) stage 1, (b) stage 1618, (c) stage 20, (d) stage 21, (e) stage 25, (f) stage 38, (g) stage 42, (h) stage 44, and (i) stage adult (Photographed by Boby Darmawan). 
Rearing tadpoles and near-hatched eggs were more successful than rearing newly-laid eggs. Although our first attempt to grow tadpole ended with only one tadpole surviving to stage 43 , our second attempt to rear stage 23-24 eggs (near hatching period) resulted in greater success with nearly $30 \%$ of the eggs still surviving as tadpoles until 4 December 2008 . The development of fertilised eggs of C. vittiger is shown in Fig. 7.

\section{Larva Description and Development}

Tadpoles show an oval body with rounded snout (Fig. 8). The eyes situated in dorsal, directed laterally which is not visible from below. Nostril is small, dorsolateral, at midpoint between snout tip and eye. The internarial distance is about $50 \%$ of the interorbital distance. The rounded naris is moderate in size, directed dorsally and positioned closer to the snout than to the eyes. The tail musculature is strong, of almost uniform height until the midtail; in the distal half of the tail the musculature is gradually tapering and almost reaches the tail's tip. Dorsal fin does not extend onto the body; a little broader than ventral fin. Dorsal fin expands after one third of tail length, where it becomes the point of maximum fin height.

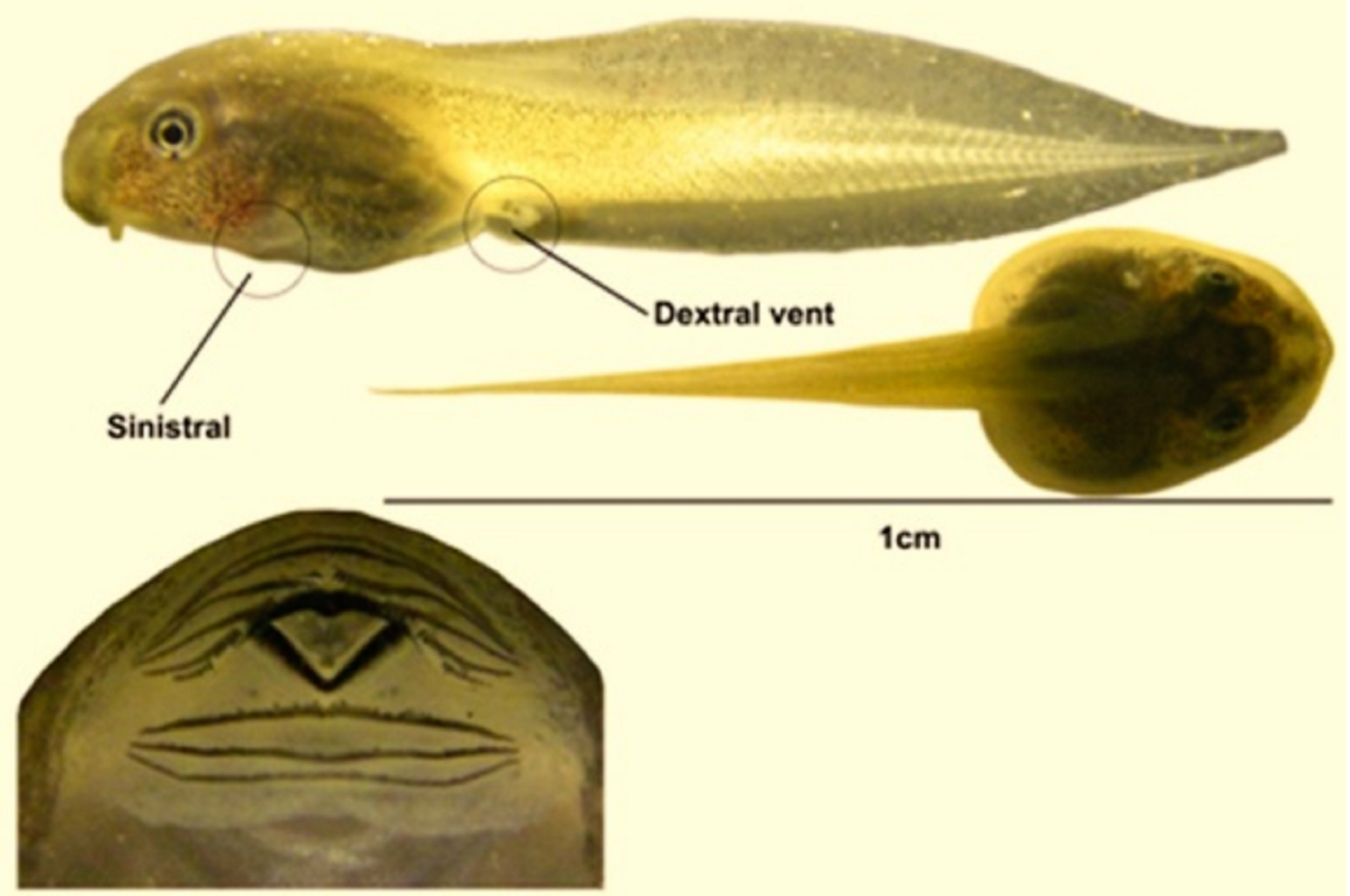

$\|+4-4 /\| I \|$

Figure 8. The characteristic of $C$. vittiger's tadpole shown by its lateral view, dorsal view and detailed mouthpart. 
Spiracle is sinistral, visible from above and below. Anus is dextral. Tail length 1.4-2.0 times body length. Mouth directed downwards with suctorial disc on the throat. Oral disc is medium, extending definitely beyond the lower jaw. The upper (suprarostral) and lower (infrarostral) supportive jaw cartilages have pigmented and keratinised jaw sheaths. The relative amount of dark keratinisation (width in longitudinal dimension) in the sheath is about half the width (medium). Margin of oral disc is emarginate. Upper sheath with broad arch, lower sheath V-shaped; margins of upper and lower jaw sheaths cuspate, rounded. Marginal papillae have a dorsal gap. Size varied according to its Goner stage. At stage 25, the total length of tadpoles ranges from $1.5-2.6 \mathrm{~cm}$. In this stage, tadpole has labial teeth formula of II+4-4/III. Dorsal surface of tadpole is transparent brown, head and body with plenty dark mottled but becoming lightly to tail. Ventral surface is transparent (Fig. 8). Morphometric measurements of eight C. vittiger tadpole specimens from stage 21 to 46 are given in Table 4.

Table 4. Morphometric measurement of eight C. vittiger tadpoles taken from different ponds at CGI concession in Mount Halimun-Salak National Park. All measurements are in mm

\begin{tabular}{|c|c|c|c|c|c|c|c|c|c|c|c|c|}
\hline NO & Code & STAGE & TL & BL & TAL & BW & МТН & ТМH & TMW & IOD & IND & ODW \\
\hline 1 & $\begin{array}{l}\text { MZB.Amph } \\
24135\end{array}$ & 41 & 25.72 & 8.42 & 15.62 & 5.52 & 5.02 & 2.72 & 2.22 & 4.12 & 2.02 & 3.24 \\
\hline 2 & $\begin{array}{c}\text { MZB.Amph } \\
24136 \\
\end{array}$ & 28 & 25.74 & 9.22 & 16.08 & 6.02 & 4.54 & 2.22 & 1.92 & 4.42 & 2.42 & 2.68 \\
\hline 3 & $\begin{array}{l}\text { MZB.Amph } \\
24137\end{array}$ & 38 & 30.32 & 10.54 & 20.02 & 6.64 & 4.78 & 2.88 & 2.32 & 5.14 & 2.82 & 2.72 \\
\hline 4 & $\begin{array}{l}\text { MZB.Amph } \\
24138\end{array}$ & 28 & 27.06 & 9.42 & 18.84 & 6.32 & 5.42 & 2.56 & 2.00 & 4.44 & 2.40 & 3.50 \\
\hline 5 & $\begin{array}{l}\text { MZB.Amph } \\
24139 \\
\end{array}$ & 36 & 28.42 & 10.22 & 17.32 & 6.00 & 5.52 & 2.42 & 1.88 & 4.42 & 2.76 & 3.34 \\
\hline 6 & $\begin{array}{c}\text { MZB.Amph } \\
24140\end{array}$ & 26 & 24.12 & 9.62 & 13.32 & 5.32 & 3.92 & 2.20 & 1.82 & 3.94 & 2.24 & 3.06 \\
\hline 7 & $\begin{array}{l}\text { MZB.Amph } \\
24142\end{array}$ & 28 & 25.00 & 8.74 & 14.82 & 5.62 & 4.32 & 2.22 & 1.64 & 4.10 & 2.04 & 2.86 \\
\hline 8 & $\begin{array}{l}\text { (Unspecified } \\
\text { number) }\end{array}$ & 38 & 22.42 & 9.82 & 12.14 & 5.90 & 4.84 & 2.42 & 1.88 & 4.54 & 2.32 & 3.60 \\
\hline
\end{tabular}

TL: Total Length; BL: Body Length; TAL: Tail Length; BW: Body Width; MTH: Maximum Tail Height; TMH : Tail Muscle Height; TMW: Tail Muscle width; IOD: Inter Orbital Distance; IND: Inter Narial Distance; ODW: Oral Disc Width. Seven tadpoles' specimen have been stored at Museum Zoologicum Bogoriense 


\section{DISCUSSION}

This survey revealed that Chiromantis vittiger has a free tadpole stage, and has a similar morphological appearance to C. trilaksonoi (Riyanto \& Kurniati 2014), however based on the call characteristics we are certain that the species we studied is non-conspecific. Riyanto \& Kurniati (2014) did not examine $C$. vittiger from its type locality in Pengalengan, therefore genetic studies about this species from its distribution seem indispensable in order to ensure its suitable nomenclature in the taxonomy tree. The call oscillogram from Riyanto \& Kurniati (2014) study and our study is illustrated in Fig. 9.

The distribution of $C$. vittiger in the CGI concession is restricted to the availability of ponds especially the semi-natural ones which are quite plenty in CGI area. However, we cannot determine the population status of this species since there are no previous reports on the preceding population. Still, by judging at the number of individuals and breeding activity and habitat discovered during the survey, we assume that the current population of $C$. vittiger in CGI is quite healthy. There
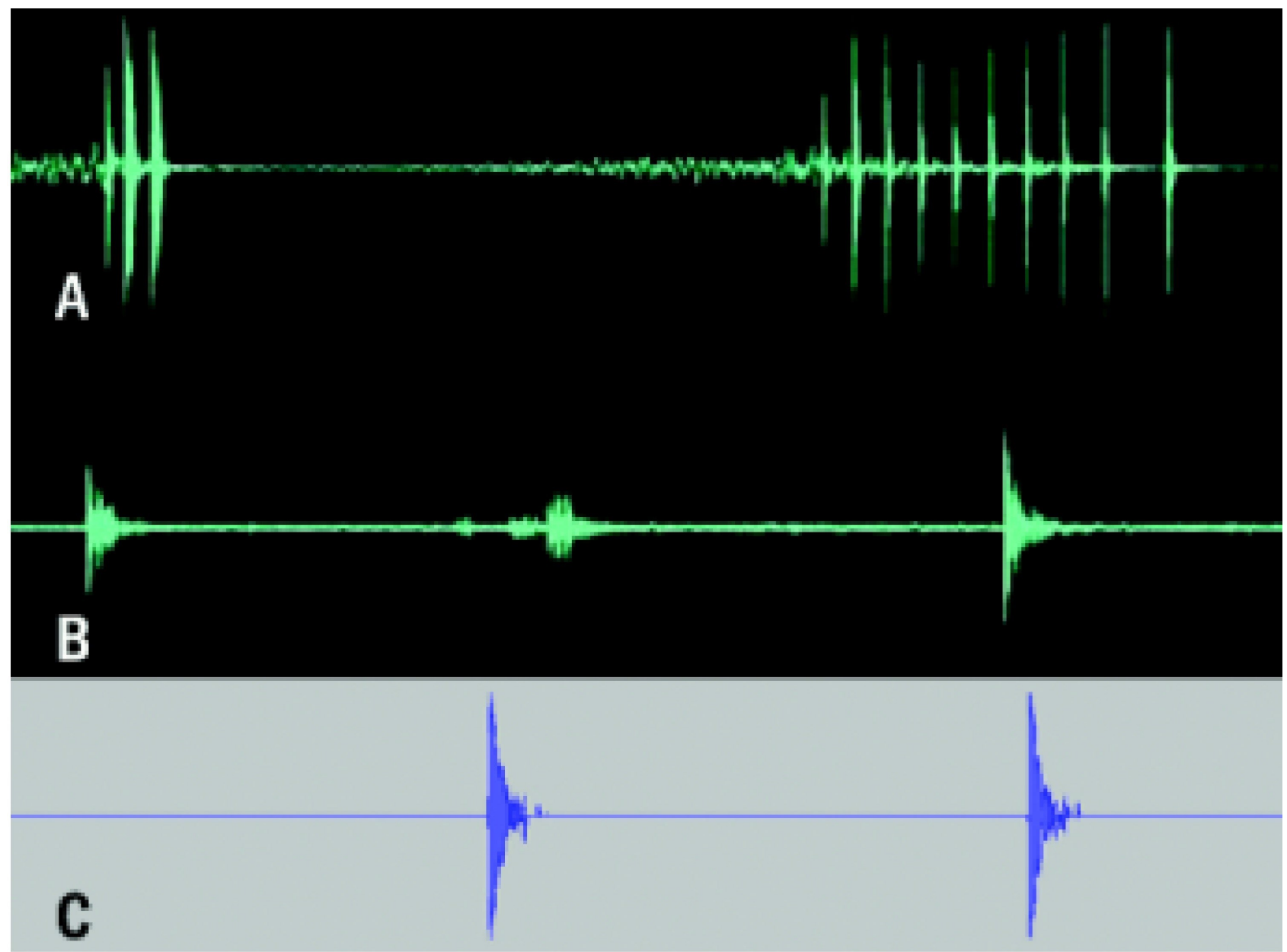

Figure 9. Comparison on oscillograms of call of Chiromantis trilaksonoi and C. vittiger. Short and long call type of C. trilaksonoi (A) and oscillogram of call of C. vittiger (B) based on Riyanto \& Kurniati (2014), and oscillogram of call of $C$. vittiger based on our field recording $(\mathrm{C})$. 
appears to be no adverse impact of the occurrence of geothermal concession within Halimun-Salak National Park to the population and habitat of this species.

During the sixth month period of observation, we found both calling males and developing eggs in the sites. Nonetheless, May is the month when we found the highest number or nest of this species. It seems that the breeding peak coincided with the timing of rain, which is similar to observations on other tropical species (Church 1960, Church 1961, Inger \& Bacon 1968, Premo 1985, Jaafar 1994). In addition, the semi-natural pond allows holding the water for a long period which is necessary for larval development of this species. The presence of these ponds may facilitate year-round breeding.

The intrusion of another male during amplexus of $C$. vittiger in this research shows an instance of mate piracy that also occurs in other species (Byrne \& Roberts 1999, Davis \& Roberts 2004, Vieites et al. 2004). Yazid (2006) reported the unsuccessful attempt of other non-selected males to engage in the mating process during amplexus of a pair of Rhacophorus reinwardtii in Bogor which was eventually ousted by the pair. However, we have seen a female of $R$. reinwardtii during oviposition with three males on her back in Bodogol at Mount Gede-Pangrango National Park (Kusrini, unpub. data) without apparent act of protestation. No aggressive behaviour is obvious during the intrusion of another male of $C$. vittiger in our observations. Since we were unable to observe amplexus in the wild, we are unsure if this kind of polyandrous mating and non-resistance behaviour of the paired frogs to the other male is common in this frog.

Although we are unable to quantify the survival of embryos to the hatching period and through metamorphosis stage, it is clear that developing embryos are vulnerable to risk of predation and desiccation prior to hatching. The presence of other important aspects such as parental care and climatic features are indispensable. Our laboratory work had shown that rearing newly fertilised eggs proved unsuccessful without the attendance of its parent. Even in the wild, some of the eggs were broken dead when there were no adults to guard it for a long period. In addition, hatched tadpoles that had difficulty sliding into the water and that remained stuck on the leaf might eventually die. Rainfall might be helpful during the hatching period by providing an escape route to the water. Newly hatched larvae devour attached algae. However, during our lab experiment, the older tadpoles also ate Tubifex worms and body parts of dead conspecifics. The food habits of $C$. vittiger tadpoles are apparently similar to those of Polypedates leucomystax who also ate carcasses of conspecific tadpoles (Alcala 1962, Yorke 1983).

Other research elsewhere have shown that most common parental care occurs mostly in the form of egg attendance (Wells 1977, Lehtinen 2003, Poo \& Bickford 2013) with the intention of reducing risk of embryonic mortality (Taigen et al. 1984, Croshaw \& Scott 2005). The adult 
removal experiment in the field revealed the critical contribution of egg attendance to offspring surivorship (Poo \& Bickford, 2013). Eggs might be defended by a male, female or both (Wells 1977), or by either the male or the female parent but not both which is called amphisexual that occurs in two species of Mantidactylus (Mantellidae) from Madagascar's rain forest (Lehtinen 2003). In the case of $C$. vittiger, parental females seem to have a larger role in guarding eggs, although parental males were often seen nearby. It is not clear whether males have roles in guarding eggs or rather guarding their territories. However, the parental care behaviour of amphibian in South East Asia is poorly known (Poo \& Bickford 2013). This includes Indonesian species, where parental care in the form of egg attendance has only been reported from two species of frogs from Sulawesi, Limnonectes arathooni (Brown \& Iskandar 2000) and Limnonectes modestus (Lubis et al. unpubl. data). In both species, male individuals were seen guarding clutches of eggs in a terrestrial nest (L. arathooni) and in a leaf (L. modestus). The wiping of eggs by the hind limb of its guardian, as observed for a $C$. vittiger female after returning from water, is presumably to maintain the moisture of its eggs by transferring water from the hind limbs to the eggs. Similar action has also been observed in other species, such as Dendrobates pumilio in which males urinate on their eggs (Weygoldt 1980) and male Chirixalus effingeri (Chen et al. 2007) which transferred moisture using its ventral surface.

\section{ACKNOWLEDGMENTS}

This work is made possible from funding from Chevron Corporation to the Wildlife Trust in partnership with Peka Foundation Indonesia. Appreciation is given to Jodi Rowley for her advice during research and Nancy E. Karraker for her comments and advice during the writing of the manuscript. Martin Fisher and four anonymous reviewers have also given advice for this, for these we are grateful. We thank the management of Chevron Geothermal Indonesia for access and assistance during field works. We thank Damayanti Buchori, Shinta Puspitasari, Bandung Sahari, Wika, Heri Tabadepu, and Iyus, from Peka Foundation for advice and assistance in the field. We are grateful for the assistance of Ucup, Jejen and family who had shared their house with us. Dede Hendra Setiawan, Asyrafi, Nurikhwan Khusaini, Akmal Firdaus, Arief Tajalli, Benny Aladin and Neneng Sholihat had volunteered their time in the field.

\section{REFERENCES}

Alford, R.A. \& S.J. Richards 1999. Global amphibian declines: a problem in applied ecology. Annual Review of Ecology and Systematics 30: 133-165.

Alcala, A.C. 1962. Breeding behaviour and early development of frogs of Negros, Philippine islands. Copeia 1962: $679-726$. 
Brown, R.M. \& D.T. Iskandar 2000. Nest site selection, larval hatching, and advertisement calls, of Rana arathooni from southwestern Sulawesi (Celebes) island, Indonesia. Journal of Herpetology 34: 404413.

Bossuyt, F. \& A. Dubois 2001. A review of the frog genus Philautus Gistel, 1848 (Amphibia, Anura, Ranidae, Rhacophorinae). Zeylanica 6: 1-112.

Boulenger, G.A. 1897. Descriptions of new Malay frogs. Annals and Magazine of Natural History, Series 6, 19: $106-108$.

Byrne, P.G. \& J.D. Roberts 1999. Simultaneous mating with multiple males reduces fertilization success in the myobatrachid frog Crinia georgiana. Proceedings of the Royal Society Biological Sciences 266: 717-721.

Chen, Y.H., H.T. Yu \& Y.C. Kam 2007. The ecology of male egg attendance in an arboreal breeding frog, Chirixalus eiffingeri (Anura: Rhacophoridae), from Taiwan. Zoological Science 24: 434-440.

Church, G. 1960. The effects of seasonal and lunar changes on the breeding pattern of the edible Javanese frog, Rana cancrivora Gravenhorst. Treubia 25: 215-233.

Church, G. 1961. Seasonal and lunar variation in the numbers of mating toads in Bandung (Java). Herpetologica 17: 122-126.

Croshaw, D.A. \& D.E. Scott 2005. Experimental evidence that nest attendance benefits female marbled salamanders (Ambystoma opacum) by reducing egg mortality. The American Midland Naturalist 154: $398-411$.

Davis, R. A. \& J.D. Roberts 2004. Operational sex ratio and mating behaviour of the myobatrachid frog Neobatrachus kunapalari. Journal of the Royal Society of Western Australia 87: 97-99.

Gosner, K.L. 1960. A simplified table for staging anuran embryos and larvae with notes on identification. Herpetologica 16: 183-190.

Gridi-Papp, M. 2007. Sound Ruler acoustic analysis. v. 0.9.6.0. Available via SourceForge. $\mathrm{http}: / /$ soundruler.sourceforge.net (version 0.9.6.0).

Howard, S.D. \& D.P. Bickford 2014. Amphibians over the edge: silent extinction risk of data deficient species. Diversity and Distributions 20: 837-846.

Inger, R.F. \& J.P. Bacon Jr. 1968. Annual reproduction and clutch size in rain forest frogs from Sarawak. Copeia 1968: 602-606.

Iskandar, D.T. 1998. Amfibi Jawa dan Bali - Seri Panduan Lapangan. Puslitbang - LIPI. Bogor, Indonesia, $132 \mathrm{pp}$.

Iskandar, D. T. \& W.R. Erdelen 2006. Conservation of amphibians and reptiles in Indonesia: issues and problems. Amphibian and Reptile Conservation 4: 60-93.

Iskandar, D., Mumpuni, M. Kusrini \& A. Angulo 2009. Philautus vittiger. The IUCN Red List of Threatened Species. Version 2015.2. [Online] <www.iucnredlist.org> [Accessed on 25 July 2015].

Jaafar, I.H. 1994. The life history, population and feeding biology of two paddy field frogs, Rana cancrivora Gravenhorst and R. limnocharis Boie, in Malaysia. PhD Dissertation, University Pertanian Malaysia, Malaysia. 228 pp.

Kurniati, H. 2003. Amphibians and Reptile of Gunung Halimun National Park West Java, Indonesia (Frog, Lizard and Snake). Puslitbang Biologi LIPI. Cibinong, Indonesia, 134 pp.

Kusrini, M.D. \& A. Fitri 2006. Ecology and Conservation of Frogs of Mount Salak, West Java, Indonesia. Unpublished report to Wildlife Trust. Department of Forest Resources Conservation, Faculty of Forestry, Bogor Agricultural University, Bogor, $30 \mathrm{pp}$.

Lehtinen, R.M. 2003. Parental care and reproduction in two species of Mantidactylus (Anura: Mantellidae). Journal of Herpetology 37: 766-768. 
Morais A.R., M.N. Siqueira, P. Lemes, N.M. Maciel \& P. De Marco 2013. Unraveling the conservation status of data deficient species. Biological Conservation 166: 98-102.

Nori, J. \& R. Loyola 2015. On the worrying fate of Data Deficient amphibians. PLoS ONE 10: e0125055

Poo, S. \& D.P. Bickford 2013. The adaptive significance of egg attendance in a South-East Asian tree frog. Ethology 119: 671-679.

Premo, D.B. 1985. The reproductive ecology of a ranid frog community in pond habitats of West Java, Indonesia. PhD Dissertation. Michigan State University, USA, 184 pp.

R Core Team 2017. A language and environment for statistical computing, issued 2017. https://www.rproject.org/

Riyanto, A. \& H. Kurniati 2014. Three new species of Chiromantis Peters 1854 (Anura: Rhacoporidae) from Indonesia. Russian Journal of Herpetology 21: 65-73.

Rowley, J., R. Brown, R. Bain, M. Kusrini, R. Inger, B. Stuart, G. Wogan, N. Thy, T. Chan-Ard, C. T. Trung, A. Diesmos, D.T. Iskandar, M. Lau, L.T. Ming, S. Makchai, N.Q. Truong \& S. Phimmachak 2010. Impending conservation crisis for South-East Asian amphibians. Biological Letters 6: 336338.

Stoliczka, F. 1870. Observations on some Indian and Malayan Amphibia and Reptilia. Proceedings of the Asiatic Society of Bengal 1870: 103-109.

Stuart, S. N., J.S. Chanson, N.A. Cox, B.E. Young, A.S.L. Rodrigues, D.L. Fischman \& R. W. Waller 2005. Status and trends of amphibian declines and extinctions worldwide. Science 306: 1783-1786.

Taigen, T.I., E.H. Pough \& M.M. Stewart 1984. Water balance of terrestrial anuran (Eleutherodactylus coqui) eggs: importance of parental care. Ecology 65: 248-255.

Vieites, D.R., S. Nieto-Roma'n, M. Barluenga, A. Palanca, M. Vences \& A. Meyer 2004. Post-mating clutch piracy in an amphibian. Nature 431: 305-308.

Wells, K.D. 1977. The social behavior of anuran amphibians. A nimal Behavior 25: 666-693.

Weygoldt, P. 1980. Complex brood care and reproductive behavior in captive poison-arrow frogs, Dendrobates pumilio O. Schmidt. Behavioral Ecology and Sociobiology 7: 329-332.

Wostl, E., A. Riyanto, A. Hamidy, N. Kurniawan, E.N. Smith \& M.B. Harvey 2017. A taxonomic revision of the Philautus (Anura: Rhacophoridae) of Sumatra with the description of four new species. Herpetological Monographs 31(1): 98-141. https://doi.org/10.1655/HERPMONOGRAPHS-D-1600007.

Yazid, M. 2006. Perilaku berbiak katak pohon hijau (Rhacophorus reinwardtii Kuhl \& van Hasselt, 1822) di kampus IPB Darmaga. BSc Research Thesis. Institut Pertanian Bogor, Bogor, Indonesia, 51 pp.

Yorke, C.D. 1983. Survival of embryos and larvae of the frog Polypedates leucomystax in Malaysia. Journal of Herpetology 17: 235-241. 